\title{
Effect of pesticides on microbial diversity on agricultural soil in the locality of Akonolinga in the Centre Region - Cameroon
}

\author{
Manga Anaba Désiré ${ }^{1,2, *}$, Anaba Manga Jacques Denis ${ }^{1}$, Ngono Ambassa Véronique ${ }^{1}$, Kuate Tueguem \\ William Norbert 2 , Ndongo Bekolo ${ }^{2}$ and Biye Elvire Hortense 1

\begin{abstract}
${ }^{1}$ Laboratory of Environmental Management and Plant Production, Department of Plant Biology, Faculty of Science, University of Yaounde I, PO Box 812, Yaounde-Cameroon.

2 Laboratory of Phytopathology and Crop Protection, Department of Plant Biology, Faculty of Science, University of Yaounde I.
\end{abstract}

Magna Scientia Advanced Research and Reviews, 2021, 02(01), 028-039

Publication history: Received on 04 March 2021; revised on 10 April 2021; accepted on 13 April 2021

Article DOI: https://doi.org/10.30574/msarr.2021.2.1.0031

\begin{abstract}
Bacteria and fungi constitute microorganisms which provide essential services to the soil ecosystem, not only for the maintenance of its fertility, but also for the degradation of certain pollutants. The present study was carried out to evaluate the effects of a synthetic fungicide and seed extracts of two fungicidal plants (Anonidium mannii and Ricinus communis) on microorganisms in an agricultural soil sample. With the solvents acetone, water and methanol, seed extracts of $A$. mannii and R. communis were used for phytochemical screening and for the preparation of solutions with concentrations of $50 \mu \mathrm{l} / \mathrm{ml}$ corresponding to fungistatic doses. For microbial colony enumeration, 10-1 dilutions for fungi and 10-2 dilutions for bacteria were spread on the surface of SCA medium supplemented with recommended doses of the chemical fungicide and $50 \mu \mathrm{l} / \mathrm{ml}$ concentrations of $A$. mannii and $R$. communis seed extracts. Petri dishes containing these mixtures are incubated with bacteria at $30^{\circ} \mathrm{C}$ for 24 hours and with the fungi for 7 days. At the end of each period, the types of microorganisms are differentiated by the colours of the colonies formed. For doses recommended for farmers, the chemical fungicide Monchamp 720WP destroys all bacterial and fungal life on solid SCA agar. In extracts containing abundant alkaloids, bacterial colony counts are low while in extracts containing metabolites, bacterial colonies are high. Different groups of fungi were differentiated by the coloration of the colonies formed. A significant number of fungal colonies of different colours were observed in the presence of extracts containing alkaloids and sterols/triterpenes. Microbial diversity will reduce the bactericidal and fungal activity of the plant extracts used and will favour their multiplication in the media. The inability of these plant extracts to destroy microorganisms continues to provide beneficial ecologically services to the ecosystem which ensures soil fertility and environmental preservation. Thus, the use of these plant extracts ensures good environmentally agriculture.
\end{abstract}

Keywords: Anonidium mannii; Ricinus communis; Phytochemical screening; Microorganisms; Solvents.

\section{Introduction}

Agriculture is an important activity that contributes to the socio-economic development of the population. Unfortunately, agricultural production is highly affected by pests and the plants diseases. To meet the ever-increasing demands of market, yields are improved by the use of chemical pesticides [1], [2]. Domestic sales of synthetic pesticides in Cameroon increased from CFAF 3.6 billion in 1991 to CFAF 12.2 billion in 2000 . Due to business agreements with the European Union, the $100 \%$ drop in customs duties had led to the intensive importation and use of these chemical

\footnotetext{
* Corresponding author: Manga Anaba Désiré, +237 699938544, desiremanga62@gmail.com

${ }^{1}$ Laboratory of Environmental Management and Plant Production, Department of Plant Biology, Faculty of Science, University of Yaounde I, PO Box 812, Yaounde-Cameroon.
} 
pesticides in Cameroon since August 2019. It should be noted that the continuous use of chemical pesticides impoverishes the soil.

Soil contains microorganisms which is the backbone of several nutrient cycles [3]. Depending on their specificity, these microorganisms provide some essential services to the ecosystem such as; decomposition of organic matter and their cycling, regulation and absorption of nutrients, plant resistance to diseases and pests, gas exchange and carbon sequestration, soil detoxification and control of plant growth [4], [5], [6].

Thus, bacteria and fungi mechanisms on rocks, release mineral nutrients into the soil [5]. Out of 1542 USD/year which is the overall economic value of various services provided by soil organisms to the ecosystem, 1317 USD/year is the estimated global economic benefits due to soil microbial diversity [7]. Soil microflora include; microorganisms with no impact, with adverse effects on the plant, or with beneficial effect on the plant. Depending on the genus of bacteria or fungi, these microorganisms (nitrogen-fixing bacteria, mycorrhizal fungi, rhizobacteria) either harm or promote plant growth and health [3].

Bacteria are unicellular living microorganisms present in all environments, particularly in the rhizosphere, which is the site for intense essential microbial activities for plant nutrition and functioning of the ecosystem [8], [9]. Filamentous bacteria (actinomycetes) grow on a wide range of substrates colonising almost all environments, and play an important role in the degradation of organic matter for soil fertility [10], [11], [12], [3]. Bacteria are essential for the functioning of nitrogen and biogeochemical carbon cycles. From an agronomic point of view with respect to their functional groups, the most important bacteria are ammonifying, nitrogen-fixing, nitrifying, cellulosic and pectinolytic bacteria [13]. During their development and multiplication in solid agar culture media, bacteria form regular clusters called bacterial colonies, visible to the naked eye after 24-48 hours [14], [3].

Alongside bacteria, fungi are also a dominant group of microorganisms present in the soil where they play important roles in the functioning of their ecosystems [3], [15]. Compared to other microorganisms, fungi play an important role in the decomposition of organic matter, nutrient cycling and degradation of large quantities of biomass. For example, species of the genus Fusarium are very aggressive, more damaging and predominant to cultivated plants [16], [17]. Specifically, the species Fusarium solani has the ability to degrade some Polycyclic Aromatic Hydrocarbons at a rate of more than 30\% [18]. However, soil-borne filamentous fungi responsible for cryptogamic plant diseases, degradation of various organic pollutants and pesticides in the soil are destroyed by synthetic fungicides; [19], [20].

Under natural conditions, bacteria and fungi are in dynamic equilibrium in the soil and with plants; where their prevalence in the soil, their capacity to benefit and cause infections to plants, attest their importance in the environment depending on the species. Conventional agriculture negatively affects microbial populations, symbiotic associations, microbial activities in the rhizosphere, the release of mineral nutrients from decomposing organic matter or weathering rocks [5]. These agricultural practices also reduce the presence of pathogenic microorganisms on crops [3] and the soil loses its fertility and microbiological activity. In conventional agricultural practices, pesticides are used to protect crops from various threats and to increase crop productivity. However, prolonged or inappropriate use of pesticides can lead to chemical pollution of the environment and destruction of soil biodiversity.

Chemical pollution of the soil resulting from pesticides reduces the abundance and diversity of organisms. However, some of these plant protection products are specific and affect certain microorganisms such as fungi and bacteria [3]. Furthermore, under specific environmental conditions and through specific mechanisms, some soil microorganisms degrade pesticides [21], [22], [23]. Bacteria, abundant microorganisms in agricultural field soils are responsible for the biodegradation of chemical pesticide molecules [24]. Results from the work of [25], and [26] show that prolonged use of the pesticide Endosufan, reduces the bacterial population and frequent use of Dimethoate leads to a decrease in the fungal population. In cotton agrosystems in Burkina Faso, the work of [27], and [28] showed a reduction in soil microbial biomass after pesticide application. Results from the work of [29] showed that rhizobia are very sensitive to fungicides, especifically Mancozeb which inhibited 95\% of the strains studied. [30], [31] have shown that fungicides are toxic to Rhizobium sp. Some pesticides disrupt the symbiotic association between rhizobium-legume due to a direct negative effect on the population of free soil bacteria; the degree of infection of the plant and the quantity of nodules formed is reduced [32]. Depending on the concentrations and type of fungicide, Rhizobium and Bradyrhizobium strains can be inhibited or not [33], [34], [31],[29]. The laboratory studies, [35] and [36] have shown that pesticide doses close to those recommended to farmers have no impact on the population of soil microflora.

Anonidium mannii, a tropical African plant precisely Central and West Africa, is a fruit tree of dense and gallery forests, 10 to $30 \mathrm{~m}$ high, with large green leaves and a dense crown. Its fruits with numerous brown seeds, develop on the trunk and branches and are obtained by picking from the forest [37], [38], [39]. This plant harvested in Cameroon, show 
extracts with anti-inflammatory properties [40]. Aqueous, acetone and methanol extracts of $A$. mannii seeds significantly reduce the radial growth of mycelia of Fusarium solani and Collectotrichum lindemuthianum strains.

Ricinus communis, commonly known in French as ricin and "castor-oil-plant" in English, is another annual or perennial plant of the Euphorbiaceae family that originated from Egypt, Ethiopia and India but whose cultivation has subsequently spread to many other countries of the World [41], [42], [43], [44]. Concoctions or extracts of various plant parts are used as biofertiliser or pesticide [45]. In West Africa, [46] showed the moderate inhibition of radial growth of Alternaria solanisorauer by aqueous extract of $R$. communis leaves.

As mentioned above, soil microorganisms provide a healthy environment essential services to the ecosystem. In order to increase agricultural productivity, there is need for increase in protection of crops against pathogens responsible for various fungal diseases. This protection of plants is achieved by spraying with chemical or biological pesticides, most of which are sprayed into the soil. Generally, problems resulting from spraying of crops with pesticides are, endocrine disruption, reproductive harm, high risk of destruction to birds, mammals, arthropods and soil non-targeted macroorganisms. The objective of this study was to evaluate the microbial potentials of different pesticides on soil microorganisms in the agricultural soil of Akonolinga, Cameroon.

\section{Material and methods}

\subsection{Study site}

Located at $03^{\circ} 48^{\prime} 13^{\prime \prime} \mathrm{N} 012^{\circ} 15^{\prime} 37^{\prime \prime} \mathrm{E}$, at an altitude of $674 \pm 3 \mathrm{~m}$, at Akonolinga, in the Centre region, $110 \mathrm{~km}$ from Yaoundé capital of Cameroon. It is located in a forest area where agriculture is the main activity. The soil was sampled using the method of [47].

\subsection{Preparation of seeds extracts of $A$. mannii and R. communis}

The mature fruits of A. mannii were collected in a forest $\left(03^{\circ} 42^{\prime} 20^{\prime \prime} \mathrm{N}\right.$ and $\left.011^{\circ} 36^{\prime} 34^{\prime \prime} \mathrm{E}\right)$ in the Mfou, Mefou and Afamba Division in the Centre Region Cameroon those of R. communis were collected in the bushes of the city of Yaoundé. All these fruits were transported to the Phytopathology laboratory of the University of Yaoundé 1 and the seeds obtained were dried at room temperature for 4 to 5 weeks and then crushed using a manual mill to obtain a powder of $A$. mannii and a paste of $R$. communis. For each plant, the organic extracts were prepared by maceration of $500 \mathrm{~g}$ of powder in 2 litre of acetone and methanol solvent and kept for 72 hours according to [48] and then filtered. The filtrates obtained were transferred to a steam roaster and the extracts obtained were stored at $4^{\circ} \mathrm{C}$ in the refrigerator until use. For aqueous extractions, the powder or paste was wrapped in muslin cloth and soaked directly in water for 12 hours and then squized according to [49], [50] and the extracts obtained were used directly.

For each extract, the extraction yield was calculated using the formula below quoted by [51].

$$
\text { Yld }(\%)=\frac{\text { Mass of extract }(\mathrm{g})}{\text { Mass of powder }(\mathrm{g})}
$$

\subsection{Phytochemical screening}

The classes of secondary metabolites present in aqueous and organic extracts of $A$. mannii and $R$. communis seeds were determined by adapting standard procedures described by [52], and [53]. These techniques are based on the appearance of colour, precipitation and/or the presence of foam in the different reagents characterising each class of secondary metabolites.

\subsection{Preparation of SCA medium and culture of microorganisms}

Starch Casein Agar (SCA) medium according to [54], [55] is composed of $10 \mathrm{~g}$ of starch, $0.3 \mathrm{~g}$ of casein, $2 \mathrm{~g}$ of $\mathrm{KNO}_{3}, 2 \mathrm{~g}$ of $\mathrm{NaCl}, 2 \mathrm{~g}$ of $\mathrm{KH}_{2} \mathrm{PO}_{4}, 0.05 \mathrm{~g}$ of $\mathrm{MgSO}_{4}, 0.02 \mathrm{~g}$ of $\mathrm{CaCO}_{3}, 0.01 \mathrm{~g}$ of $\mathrm{FeSO}_{4}, 18 \mathrm{~g}$ of agar. Initial suspensions of microorganisms were prepared, after placing $1 \mathrm{~g}$ of each soil sample in test tubes containing $9 \mathrm{ml}$ of sterile distilled water, and shaking vigorously for approximately 5 minutes. Subsequently, a series of decimal dilutions were performed for each sample to $10^{-2}$. Inoculation was performed by spreading $0.1 \mathrm{ml}$ of each dilution on the surface of the previously prepared SCA medium. Petri dishes were then incubated at $30^{\circ} \mathrm{C}$ and observed daily for a minimum of 24 hours for bacteria and 7 days for fungi. 


\subsection{Enumeration of microbial colonies}

$10^{-1}$ dilutions for fungi and $10^{-2}$ dilutions for bacteria were used. Incubation was at $30^{\circ} \mathrm{C}$ for 24 hours for bacteria and 7 days for fungi. Readings and records were taken at the end of each period. Enumeration of microorganisms is based on the fact that a colony is formed from a microbial unit as described by [14]. The types of microorganisms are differentiated by the colours of the colonies. The calculation of the number $\mathrm{N}$ of microorganisms per gram of soil is obtained by the formular used by [56]:

$$
\mathrm{N}=\frac{\Sigma \mathrm{C}}{1.1 \times \mathrm{d}}
$$

- For $\mathrm{C}$ greater than 15 colonies:

$$
N=C \times \frac{1 / g}{d}
$$

- For C less than 15 colonies:

Where C represents the number of Colony Forming Units (CFU) counted and d the dilution rate of the initial solution of suspended microorganisms.

Once the SCA medium was removed from the autoclave, it was divided into 16 small sterile bottles of $120 \mathrm{ml}$ each (two bottles for T0, two bottles for F, two bottles for AAc, two bottles for AAq, two bottles for AM, two bottles for RAc, two bottles for RAAq and two bottles for RM). Once the temperature of the medium was below $50^{\circ} \mathrm{C}, 2.4 \mathrm{ml}$ of extract was introduced into each bottle, thoroughly homogenised and poured into 16 Petri dishes each. After taking $0.1 \mathrm{ml}$ of solution containing the soil, the dilutions $\left(10^{-1}\right.$ and $\left.10^{-2}\right)$ previously prepared were spread on the surface of each Petri dish. The observation of the macroscopic aspect of the fungal colonies was done by the method described by [57].

\section{Results}

\subsection{Extraction yield}

The yield and characteristics of the different extracts obtained depend on the solvent used for extraction (Table 1). For A. mannii, the methanol extraction gave the highest yield of $32.89 \%$ than the acetone and water extracts; all three extracts were brownish in colour, viscous in acetone and methanol and the extract was liquid in water. On the order hand, $R$. communis, extraction in acetone gave the highest yield of $39.67 \%$, an average yield of $36.20 \%$ with methanol and the lowest yield of $31.01 \%$ with water; all extracts where liquid with three different colours.

Table 1 Extraction yields and characteristics of extracts obtained with $500 \mathrm{~g}$ of seeds.

\begin{tabular}{|l|l|c|l|}
\hline Plants species & Solvent & Yield (\%) & Characteristic \\
\hline \multirow{3}{*}{ A.mannii } & Acetone & 14.67 & brownish and viscous \\
\cline { 2 - 4 } & Methanol & 32.89 & brownish and very viscous \\
\cline { 2 - 4 } & Water & 25.40 & brownish and liquid \\
\hline \multirow{3}{*}{ R. communis } & Acetone & 39.67 & brownish liquid and oily \\
\cline { 2 - 4 } & Methanol & 36.20 & Yellowish, oily and liquid \\
\hline & Water & 31.01 & Milky, Creamy and liquid \\
\hline
\end{tabular}

\subsection{Phytochemical screening of extracts}

The phytochemical screening reveals the presence of the following compounds; a persistent and thick foam for saponins; white precipitates for phenols, pale yellow colour for alkaloids, purplish red colour for terpenes, dark blue for tannins and greenish blue for sterols. Alkaloids are abundant in extracts of $A$. mannii with acetone, water and methanol; they are present in extracts of $R$. communis with the same solvents. Phenols and saponins are abundant in the aqueous extracts of both plant species and present in the extracts of $A$. mannii with acetone and abundantin $R$. communis with methanol. Sterols and triterpenes are very abundant in the methanol and acetone extracts of $A$. mannii and in the acetone 
extract of R. communis; they are present in the aqueous extract of $A$. mannii and in the methanol extract of $R$. communis and absent in the aqueous extract of $R$. communis. Tannins, on the other hand, are absent in the methanol extract of $A$. mannii and present in the other extracts of both plant species. Anthraquinones and flavonoids are totally absent in all the A. mannii seed extracts but present in the $R$. communis extracts except in aqueous extracts with the absence of anthraquinones (Table 2).

Table 2 Chemical composition of the different extracts of $A$. mannii and $R$. communis

\begin{tabular}{|c|c|c|c|c|c|c|}
\hline \multirow[b]{2}{*}{ Products } & \multicolumn{3}{|c|}{ A. mannii extract } & \multicolumn{3}{|c|}{ R. communis extract } \\
\hline & Acetone & Aqueous & Methanol & Acetone & Aqueous & Methanol \\
\hline Alkaloides & ++ & ++ & ++ & + & + & + \\
\hline Anthraquinones & - & - & - & + & - & + \\
\hline Flavonoides & - & - & - & ++ & + & ++ \\
\hline Phenols & + & ++ & - & - & ++ & ++ \\
\hline Saponines & + & ++ & - & - & ++ & + \\
\hline Tanins & + & + & - & + & + & + \\
\hline Sterols and triterpenes & ++ & + & +++ & +++ & - & + \\
\hline
\end{tabular}

\subsection{Effect of pesticides on soil bacteria}

After 48 hours of incubation in various Petri dishes, the chemical fungicide $\mathrm{F}$ completely inhibited the growth of bacteria; in the control medium T0, there was an average growth of bacterial colonies. In the presence of $A$. mannii extracts, there was a high formation of bacterial colonies with aqueous extract (AAq) than with the acetone (AAc) and methanol (AM) extracts. With all extracts of $R$. communis (RAc, RAq, RM), large numbers of bacterial colonies were formed (Figure 1).
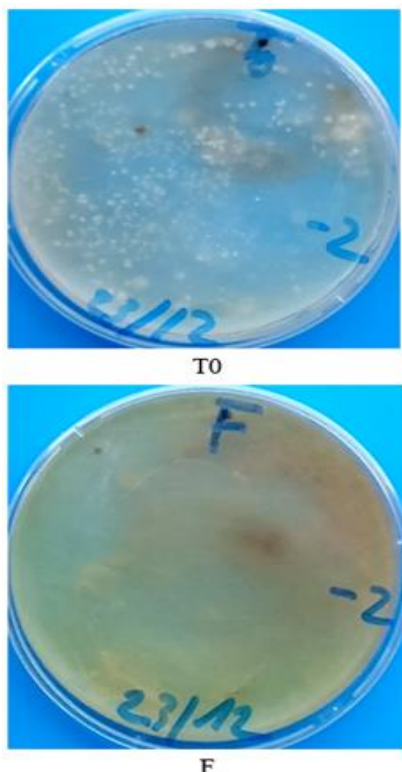

F

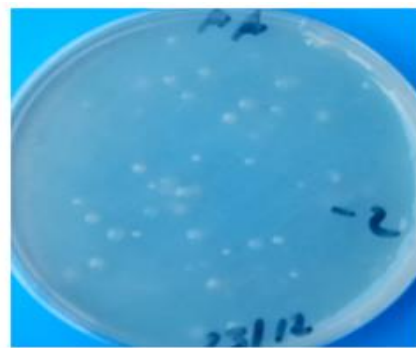

AAc

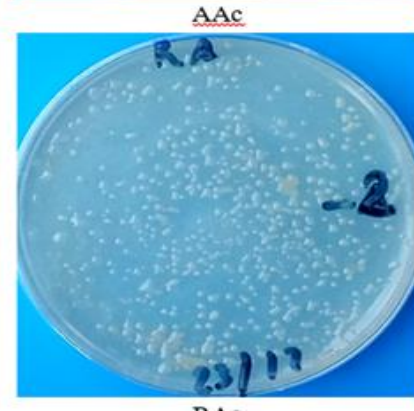

RAC

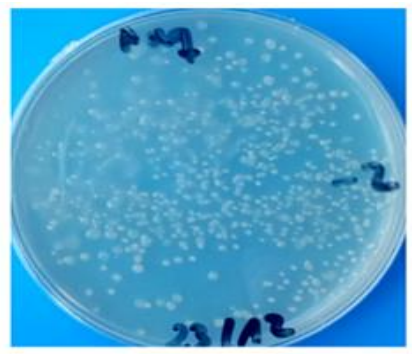

$\mathrm{AAq}$

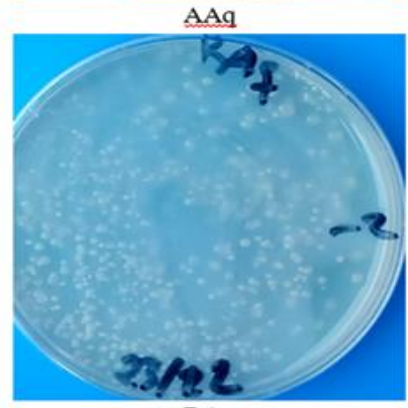

RAq

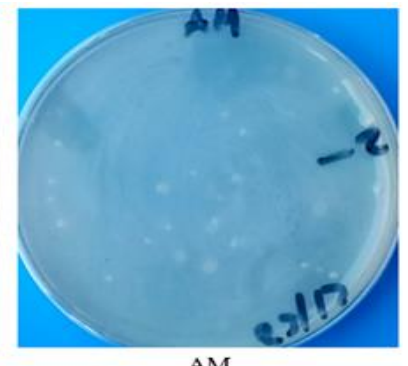

$\mathrm{AM}$

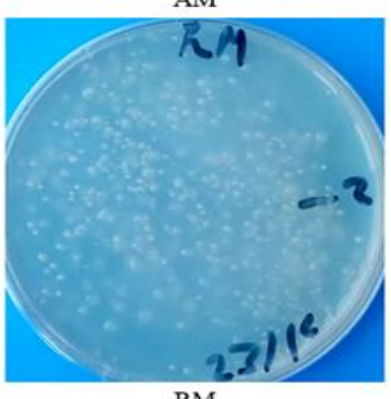

RM

Figure 1 Effect of $A$. mannii and R. communis extracts on bacterial colony formation in agar medium. Where $\mathrm{F}=\mathrm{Chemical}$ fungicide; $\mathrm{T} 0$ = Control; $\mathrm{AAq}=$ Anona aqueous extract; $\mathrm{AAc}=$ Anona acetone extract; $\mathrm{AM}=$ Anona methanol extract; $\mathrm{RAq}$ $=$ Ricin aqueous extract; $\mathrm{RAc}=$ Ricin acetone extract; $\mathrm{RM}=$ Ricin methanol extract 


\subsection{Bacterial colonies counted as a function of the treatments}

In the presence of the chemical fungicide, no bacteria grew; but in all other media, bacterial colonies were formed (Table 3). The largest amounts of bacterial colonies are formed in RAc, RM, RAq and AAq media and lowest formation of colonies in T0 medium, with 7.00x102 CFU/g.

Table 3 Number of CFU bacteria.

\begin{tabular}{|l|l|l|l|l|l|l|l|l|}
\hline Treatments & F & T0 & AAq & AAc & AM & RAq & RAc & RM \\
\hline $\begin{array}{l}\text { Nber } \\
\text { UFC/g of }\end{array}$ & 0 & $7.00 \times 102$ & $1.30 \times 104$ & $3.73 \times 103$ & $2.09 \times 103$ & $2.60 \times 104$ & $2.70 \times 104$ & $2.64 \times 104$ \\
\hline
\end{tabular}

\subsection{Effect of pesticides on soil fungi}

After 7 days of incubation, the synthetic fungicide F completely inhibited the growth of fungi in the medium, while a diversity of fungal microorganisms is observed in the control medium and seed extracts of A. mannii and R. communis (Figure 2). White and grey coloured fungi are present in AAc, AAq, AM, RAc and RM media. Black coloured fungi grew in T0, AAc, AAq, AM and RAc. The red and green coloured fungi do not appear in T0 medium; the red ones are present in the media with the different extracts of $A$. mannii and in the acetone extract of $R$. communis; the green ones are formed in the media treated with AAc, AM, RAq and RAc.

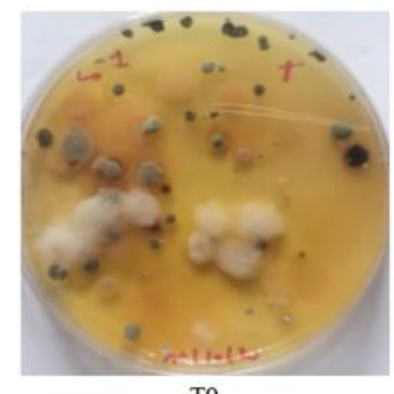

T0

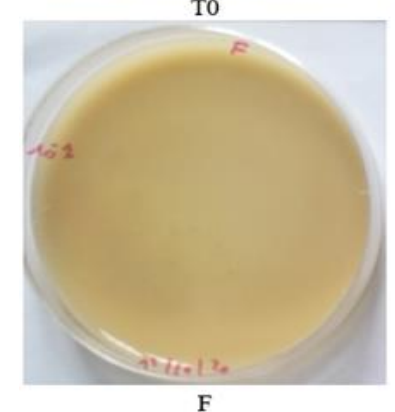

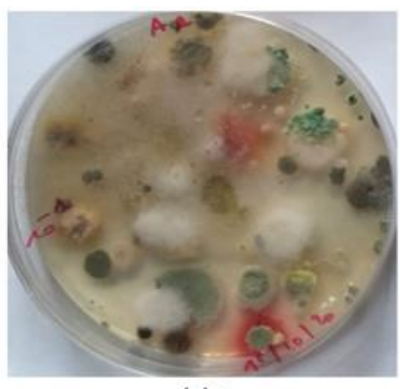

AAc

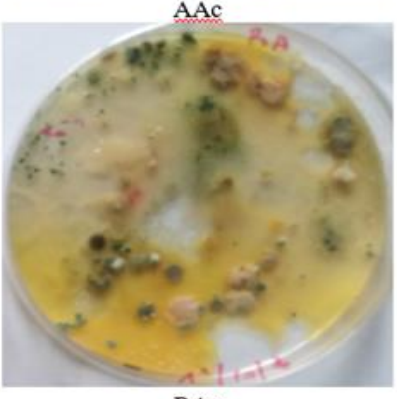

RAC
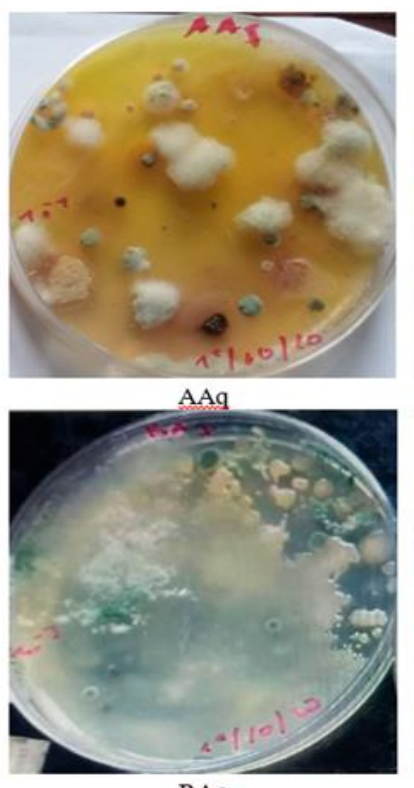

RAq

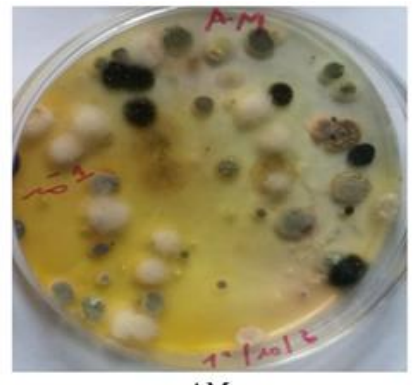

$\mathrm{AM}$

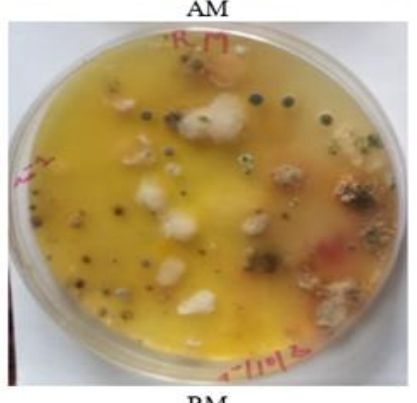

Figure 2 Effect of pesticides on colony formation of fungal microorganisms. With $\mathrm{F}=$ Chemical fungicide; $\mathrm{T} 0$ = Control; $\mathrm{AAq}=$ Anona aqueous extract; $\mathrm{AAc}=$ Anona acetone extract; $\mathrm{AM}=$ Anona methanol extract; $\mathrm{RAq}=$ Ricin aqueous extract; RAc $=$ Ricin acetone extract; RM = Ricin methanol extract; $\mathrm{CFU} / \mathrm{g}=$ Colony-forming units per gram of soil; ND = Not determined.

\subsection{Fungal colonies counted according to treatments}

The highest number of green coloured fungi (3.64 x102 CFU/g) grew in RAc medium, followed by grey (1.82x102 $\mathrm{CFU} / \mathrm{g})$ in AM medium and white $(1.82 \times 102 \mathrm{CFU} / \mathrm{g}$ and $1.64 \times 102 \mathrm{CFU} / \mathrm{g})$ in RAc and RM media; the lowest amounts (9 $\mathrm{CFU} / \mathrm{g}$ ) were observed for reds in AM medium and black in RAc medium (Table 4). The greatest diversity of fungi is observed in AAc medium with 6 different groups; followed by AM and RAc media with 5 groups and lastly RAq medium with 2 groups of fungi (Table 3 ). 
Table 4 Number of fungal CFU per treatment.

\begin{tabular}{|l|c|c|c|c|c|c|c|}
\hline \multirow{2}{*}{ Treatments } & \multicolumn{6}{|l|}{ Number of UFC/g according to the colours of the colonies } & $\begin{array}{l}\text { Number } \\
\text { of groups }\end{array}$ \\
\hline & White & Grey & Yellow & Black & Red & Green & \\
\hline T0 & $7.0 \times 10^{1}$ & $1.40 \times 10^{2}$ & 00 & $1.30 \times 10^{2}$ & 00 & 00 & 3 \\
\hline F & 00 & 00 & 00 & 00 & 00 & 00 & 0 \\
\hline AAq & $1.45 \times 10^{2}$ & $7.0 \times 10^{1}$ & 00 & $2.0 \times 10^{1}$ & $3.0 \times 10^{1}$ & 00 & 4 \\
\hline AAc & $1.40 \times 10^{2}$ & $1.10 \times 10^{2}$ & $2.0 \times 10^{1}$ & $2.0 \times 10^{1}$ & $2.0 \times 10^{1}$ & $4.0 \times 10^{1}$ & 6 \\
\hline AM & $1.45 \times 10^{2}$ & $1.82 \times 10^{2}$ & 00 & $5.0 \times 10^{1}$ & $1.0 \times 10^{1}$ & $3.0 \times 10^{1}$ & 5 \\
\hline RAq & ND & 00 & 00 & 00 & 00 & $3.64 \times 10^{2}$ & 2 \\
\hline Rac & $1.82 \times 10^{2}$ & $9.0 \times 10^{1}$ & 00 & $1.0 \times 10^{1}$ & $2.0 \times 10^{1}$ & $3.64 \times 10^{2}$ & 5 \\
\hline RM & $1.64 \times 10^{2}$ & $1.36 \times 10^{2}$ & 00 & 00 & $2.0 \times 10^{1}$ & 00 & 3 \\
\hline
\end{tabular}

$\mathrm{F}=$ Chemical fungicide; $\mathrm{T} 0$ = Control; $\mathrm{AAq}=$ Anona aqueous extract; $\mathrm{AAc}=$ Anona acetone extract; $\mathrm{AM}=\mathrm{Anona}$ methanol extract; $\mathrm{RAq}=$ Ricin aqueous extract; RAc $=$ Ricin acetone extract; RM = Ricin methanol extract; CFU $/ \mathrm{g}=$ Colony Forming Units per gram of soil; ND = Not determined

\section{Discussion}

The extraction of $500 \mathrm{~g}$ of $A$. mannii and $R$. communis powder shows a variation in yields depending on the solvents used. Extraction yields methanol with R. communis and A. mannii (36.20\% and $32.89 \%$ respectively) are higher than those of water with $R$. communis $(31.01 \%)$ and A. mannii (25.40\%). The conditions of the plant material at the time of collection that is, the plant cycle, environmental conditions and the solvent used could account for this variation in yield. [58], using Moringa oleifera leaves, and [59], using Thevetia peruviana seeds, showed that extraction yields were better with methanol than with water. Phytochemical analyses show that extracts of $A$. mannii and $R$. communis contain numerous secondary metabolites such as alkaloids, phenols, saponins, sterols and triterpenes. According to [60], [61], [62] and [63], the molecules most often responsible for antimicrobial activity are phenols, terpenoids and alkaloids respectively.

Research works have shown that flavonoids, tannins, sterols and saponins also have strong antimicrobial capacities and negatively affect the growth of isolated strains of rhizospheric bacteria and fungi [64], [65]. In a medium of Monchamp 720WP (chemical fungicide), at the dose recommended to farmers, no bacterial colonies were formed after 24 hours of incubation. This result is similar to that obtained from the work of [29] in vitro which shows that, the chemical fungicides Captan and Mancozeb inhibit the growth of bacteria strains of the genera Rhizobium, Sinorhizobium and Mezorhizobium at $95 \%$. In addition, this work had shown that large numbers of bacterial colonies were formed in the presence of 50 $\mu \mathrm{l} / \mathrm{ml}$ doses of $A$. mannii and $R$. communis extracts which contain abundant phenols. These phenols would be biodegraded by the bacteria present in the medium. Indeed, some bacteria have a strong capacity to degrade phenol [66], [67] and [68]. [69] also highlighted the biodegradation capacity of phenols by the Bacillus genus. Alkaloids show antimicrobial activity against some gram positive and negative bacteria (by [70] and [71]). This work, explains the low amount of bacterial colonies formed in AAc $\left(3.73 \times 10^{3} \mathrm{CFU} / \mathrm{g}\right)$ and $\mathrm{AM}\left(2.09 \times 10^{3} \mathrm{CFU} / \mathrm{g}\right)$ media in which alkaloids are abundant. Also, RAc $\left(2.70 \times 10^{4} \mathrm{CFU} / \mathrm{g}\right), \mathrm{RAq}\left(2.60 \times 10^{4} \mathrm{CFU} / \mathrm{g}\right)$ and RM $\left(2.64 \times 10^{4} \mathrm{CFU} / \mathrm{g}\right)$ media showed a significant amount of bacterial colonies in which alkaloids are present. Also, after seven days of incubation, no fungal colonies were formed in the presence of the chemical fungicide (Monchamp 720WP). The study of [72] in vitro, showed that the chemical fungicides Benomyl and Hymexazol inhibited the growth of Fusarium solani and Fusarium oxysporum by more than $80 \%$, but [73] showed that the bacterium Pseudomonas aeruginosa 604 was resistant to the alkaloids contained in extracts of two species of Fumaria genus (F. bastardii and F. capreolata).

From the ten colours used to differentiate mould colonies, six colours were used to detect the presence of various fungi in the different incubation media [74]. However, colouring alone cannot classify colonies of microorganisms into a precise family. In the control medium, there was the formation of three groups of fungi, whereas the seed extract medium favored the growth of many families of fungi. Due to the presence of alkaloid and sterol/triterpene metabolites, six of the fungal groups are observed in colonies (six in AAc, five in AM and four in AAq). Thus, the different type of fungi that developed could be due to the presence of the metabolites contained in the different seed extracts. The fungi 
observed at Akonolinga soil were not affected by the metabolites; although, in vitro, the phenolic compounds in the $A$. mannii extracts may cause radial growth inhibition of pure strains of $F$. solani and $C$. lindemuthianum, which are two fungal pathogens of bean plant. In this work, in the presence of diversed fungal strains, the antifungal capacities are reduced. Similarly, the works of [75] and [76], showed that Phanerocae techrysosporium is a microscopic fungus that degrades phenol. The present work shows that the different soil fungi seem to have degraded the secondary metabolites of the extracts in order to grow in large numbers. Probably, at an extract concentration of $50 \mu \mathrm{l} / \mathrm{ml}$, the microbial diversity takes over their fungicidal power. By degradation of the organic substances contained in the plant extracts, the microorganisms multiply. This could explain the formation of more colonies with certain extracts than the control medium.

\section{Conclusion}

At the dose recommended to farmers, Monchamp 720WP destroys pathogenic fungi of crops and microbial life and does not promote bacterial or fungal colony formation in the SCA solid agar medium. At the concentration of $50 \mu \mathrm{l} / \mathrm{ml}$, in the presence of secondary metabolites, aqueous, acetone and methanol extracts of A. mannii and R. communis seeds show a strong antifungal capacity on $F$. solani and $C$. lindemuthianum strains tested in vitro. However, in the presence of a mixed solution of several soil microorganisms at the same concentration, these seed extracts favoured the formation of bacterial and fungal colonies in SCA solid agar medium. This study shows that the synthetic fungicide has a negative effect on soil microbial diversity, and that the seed extracts of $A$. mannii and $R$. communis would intensify the diversity of soil bacteria and fungi. The use of A. mannii and R. communis seed extracts would be a good alternative to synthetic fungicides for the protection of cultivated plants because they intensify the provision of important ecosystem services by soil microorganisms for a better protection of the environment. The observed microbial diversity is not the same for all the extracts used; the number and type of secondary metabolites contained in these extracts could justify this difference in biological diversity. The AAc, AM and RAc extracts are more favourable to the preservation of soil microbial diversity. This study was based on the microbial colonies formed to differentiate of groups of microorganisms present in the media. It would therefore be interesting to continue this work in order to identify the families or species of microorganisms that form these coloured colonies in the presence of A. mannii and R. communis seed extracts.

\section{Compliance with ethical standards}

\section{Acknowledgments}

We would like to thank the General Management of the Institute for Agricultural Research for Development (IRAD), particularly the Mbalmayo Agricultural Research Center, and University of Yaounde I, for their contributions and support in our research.

\section{Disclosure of conflict of interest}

There is no conflict of interest among the authors or any other person.

\section{References}

[1] Kanda M, Djaneye-Boundjou G, Wala K, Gnandi K, Batawila K, Sanni A, Akpagana K. Application des pesticides en agriculture maraichère au Togo. Vertig0. 2013 ; 13 (1): 4-8.

[2] Mondédji AD, Nyamador WS, Amevoin K, Adéoti R, Abbévi Abbey G, Koffivi Ketoh G, Glitho IA. Analyse de quelques aspects du système de production légumière et perception des producteurs de l'utilisation d'extraits botaniques dans la gestion des insectes ravageurs des cultures maraichères au Sud du Togo. Int. J. Biol. Chem. Sci. 2015; 9(1): 98-107.

[3] Jeffery S, Gardi C, Jones A, Montanarella L, Marmo L. Atlas Européen de la Biodiversité des Sols. Office des Publications Officielles des Communautés Européennes. 2013; 128.

[4] Bunning S, Jimérez J. Indicators and assessment of soil biodiversity/soil ecosystem functionning for farmers and Governments. Paper presented at the OECD expert meeting on indicators of soil erosion and soil biodiversity, Rome Italy. 2003; 25-28.

[5] Haygarth P, Ritz K. The future of soils and land use in UK: soils systems for the provision of landbased ecosystem services. Land Use policy. 2009; 2 : S187-S197.

[6] FAO. Sols et biodiversité. Rome, Italie. 2015; 4. 
[7] Pimentel D, Wilson C, McCullum C, Huang R, Dwen P, Flack J, Tran Q, Saltman T, Cliff B. Economic and environmental benefits of biodiversity. Bioscience. 1997; 47 : 747-758.

[8] Séverine. La rhizosphère: un « nouveau continent à explorer » à l'interface entre sol, racines et microorganismes. Compte rendu des "jeudis de la recherche". Centre de Vulgarisation Scientifique - COMPAS. 2012.

[9] Lepinay C. Etude des interactions plantes-microbes et microbes-microbes au sein de la rhizosphère, sous un aspect coûts-bénéfices, dans un contexte de variation environnementale. Thèse de Doctorat. Sciences agricoles. Université de Bourgogne. Français. 2013; 263.

[10] Boughachiche F, Reghioua S, Oulmi L, Zerizer ., Kitouni M, Boudemagh A, Boulahrouf A. Isolement d'actinomycetales productrices de substances antimicrobiennes à partir de la sebkha de Aïn M'lila. Sciences \& Technologie. C, Biotechnologies. 2005; (23): 5-10.

[11] Naikpatil SV, Rathod JL. Selective isolation and antimicrobial activity of rare actinomycès from mangrove sediment of Karwar. Journal of Ecobiotechnology. 2011; 3(10) : 48-53.

[12] Habibeche L. Isolement et sélection de souches d'actinomycès productrices d'antibiotiques. Mémoire de Master, Université Abderrahman Mira de Bejaia. 2013; 67.

[13] Roger PA, Garcia JL. Introduction à la microbiologie du sol. Polycopié de cours, Université de la Méditerranée. $2001 ; 191$.

[14] Lhuillier. Dénombrement des microorganismes revivifiables par incorporation en gélose. École normale supérieure de Lyon Institut français de l'Éducation - ACCE École normale supérieure de Lyon Institut français de l'Éducation - ACCE. 2010; 1.

[15] Chandini KC, Rajeshwari N. Isolation and identification of soil fungi in Mattavara forest, Chikamagalur Karnataka. Journal of pharmacognosy and phytochemistry. 2017; 6(5): 721-726.

[16] Meddah N, Ouazzani Touhami A, Benkirane R, Douira A. Étude du pouvoir pathogène de quelques espèces de Fusarium sur le bananier sous serre au Maroc. Bulletin de la Société Royale des Sciences de Liège. 2011; 80: 939 $-952$.

[17] Mukamuhirwa F, Rukundo P, Kanyanga MC, Butare L. Identification of potential sources of root rot resistance among Rwandan bean lines. International Journal of Agriculture, environment and Bioresearc. 2018; 3(5): 160186.

[18] Fayeulle A. Étude des mécanismes intervenant dans la biodégradation des hydrocarbures aromatiques polycycliques par les champignons saprotrophes telluriques en vue d'applications en bioremédiation fongique de sols pollués. Thèse de Doctorat. Université du Littoral Côte d’Opale. 2013; 205.

[19] Mougin C, Chaplain V, Rama-Mercier R, Sohier L, Sigoillot JC, Asther M. Utilisation de champignons filamenteux pour la dépollution de sols pollués par des polluants organiques. Déchets, Sciences et Techniques. $1996 ; n^{\circ} 4.3$.

[20] Mercier R. Traitement par des champignons filamenteux de sols contaminés par des composés organiques persistants : application aux hydrocarbures aromatiques polycycliques. Thèse de Doctorat. Aix-Marseilles. 1998; 123.

[21] Calvet R, Barriuso E, Bedos C, Benoit C, Charnay MP, Coquet Y. Les pesticides dans le sol : conséquences agronomiques et environnementales. Editions France Agricole. 2005; 637.

[22] Savadogo PW. Pesticides et microflore du sol de la zone maraîchère des Niayes de Dakar. Rapport de stage postdoctoral de perfectionnement à la recherche. 2005; 25.

[23] Savadogo PW, Traoré O, Topan M, Tapsoba KH, Sedogo PM, Bonzi-Coulibaly LY. Variation de la teneur en résidus de pesticides dans les sols de la zone cotonnière du Burkina Faso. Journal Africain des Sciences de l'Environnement. 2007; 1: 29-39.

[24] Agoussar A. Effet des pesticides sur la diversité bactérienne des champs agricoles et la capacité des bactéries à les dégrader. Mémoire de Maîtrise, Université de Montréal. 2017; 98.

[25] Hussain A, Rafique Asi M, Iqbal Z, Chaudhry JA. Impact of heavy repeat long term pesticides applications on soil properties in a cotton agroecosystem. In : «Impact of long term pesticides usage on soil properties using radiotracer techniques ». Proceeding of final research coordination meeting. Organized by the Joint FAO/IAEA Division of Nuclear Techniques in Food and Agriculture and held in Hangzhou, Zhejiang, China, 24-28 may 
[26] Mäder P, Peng S, Fliessbach A. Effets des produits phytosanitaires sur les microorganismes du sol. VBB-Bulletin. $2002 ; 6-7$.

[27] Lompo DJP. Impact des résidus de pesticides sur les microorganismes des sols dans les agrosystèmes cotonniers du Burkina Faso. Mémoire de DEA. Université Polytechnique de Bobo Dioulasso. 2007; 60.

[28] Ouattara B, Savadogo PW, Traoré O, Koulibaly B, Sedogo MP, Traoré AS. Effet des pesticides sur l'activité microbienne d'un sol ferrugineux tropical du Burkina Faso. Cameroon Journal of Experimental Biology. $2017 ; 06$ $\mathrm{N}^{\circ} 01,11-20$.

[29] Moëz S. Effets des pesticides sur la croissance bactérienne des Rhizobia. Mémoire de Master, Université de Laval, Canada. $2003 ; 83$.

[30] Fabra A, Duffard R, Duffard AE. Toxicity of 2,4-Dichlorophenoxyacetic acid to Rhizobium sp. in pure culture. Bull. Enviro. Contam. Toxicol. 1997; 59: 645-652.

[31] Hicks RJ, Stotzkly G, Van Voris P. Review and evaluation of the effects of Xenobiotic Chemicals on Microorganisms in Soil. Advances in Applied Microbiology. 1990; 35: 195-253.

[32] Lal R, Lal S. Pesticides and nitrogen cycle. CRC Press, Inc. Boca Raton, Florida. 1988; III: 48-119.

[33] Antoun H, Couture L, Guilmette H. Effect of some systemic and protectant fungicides on growth of Verticillium alboatrum, Rhizobium meliloti and lucerne seedlings in the laboratory. Protection Ecology. 1984; 6: $279-286$.

[34] Angelini I, Fabra A, Castro S. Changes in Bradyrhizobium sp. Polysaccharides and in peanut root nodule polyamines produced by the fungicide mancozeb. Symbiosis. 1999; 27: 157-168.

[35] Topan SM. Contribution à l'étude de la dégradation des pesticides dans les sols au Burkina Faso. Mémoire d'Ingénieur du Développement Rural, Option Agronomie, IDR IUPB, Burkina Faso. 2005 ; 54.

[36] Coulibaly K. Contribution à l'étude des effets de l'endosulfan sur les paramètres biologiques de trois types de sol en zone cotonnière du Burkina Faso. Mémoire d'Ingénieur du Développement Rural, Option Agronomie, Univ. Polytech. De Bobo Dioulasso, Burkina Faso. 2006; 53.

[37] Koni MJ, Bostoen K. Noms et usages des plantes utiles chez les Nsong (RD Congo, Bandundu, Bantu B85F). Göteborg Africana Informal Series-. 2008; N6. 71.

[38] Konda KM, Mbembe B, Latham P, Bavukinina N. Plantes médicinales de traditions. Province de l'Equateur - R.D. Congo. 2012; 420.

[39] Paluku A, Bwama M, Okungo A, Tchoundjeu Z, Van Damme P. Production de plants d'Anonidium mannii (Oliver) Engler \& Diels par la multiplication végétative. Rev. Mar. Sci. Agron. Vét. 2019; 7(1): 129-136.

[40] Mokale KA, kopa KT, Pradeep P, Prem N. Pharmacological evidence of vitex thyrsiflora, Entandrophrgma cylindricum, and Anonidium mannii used for the management of inflammation in Cameroon. Journal of Basic and Clinical physiology and Pharmacology. 2020; 31(4).

[41] Trochain J. Le ricin. Journal d'agriculture traditionnelle et de botanique appliquée. 1930; 385-392.

[42] Dumeignil F. Propriétés et utilisation de l'huile de ricin. OCL. 2012; 19(1): 10-15.

[43] Dehankar PB, Bhosale VA, Patil SU, Dehankar SP, Deshpande DP. Turkey Red Oil from Castor Oil using Sulphonation Process. International Journal of Engineering Research and Technology. 2017; 10(1): $293-296$.

[44] Mvuenga EM, Lokadi PL. Evaluation of Ricinus communis Extracts as a Biopesticide for Nisotra gemella Control. Asian Research Journal of Agriculture 2017; 4(1): 1-9.

[45] Ngo T, Nguyen T, Bui D, Hoang N. Effects of ricin extracted from seeds of the castor bean (ricinus communis) on cytotoxicity and tumorigenesis of melanoma cells. Biomedical Research and Therapy. 2016; 3(5): 633-644.

[46] Bayaso I, Nahunnaro H, Gwary DM. Effects of aqueous extract of Ricinus communis on radial growth of Alternaria solani. Afr. J. Agric. 2013; 8(37): 4541-4545.

[47] Pochon J, Tadieux P. Techniques d'analyse en microbiologie du sol. Edition de la tourelle, St Mandé. 1962; 110111.

[48] Stoll. Protection naturelle des végétaux en zone tropicale. CTA, AGRECOL. 1994; 95-99.

[49] Ambang Z, Ndongo B, Amayana D, Djilé B, Ngoh JP, Chewachong GM. Combined effect of host plant resistance and insecticide application on the development of cowpea viral diseases. Austr. Jm. Crp. Sc. 2009; 3(3): 167-172. 
[50] Ambang Z, Ngoh Dooh JP, Essono G, Bekolo N, Chewachong G, Asseng CC. Effect of Thevetia peruviana seeds extract on in vitro growth of four strains of Phytophthora megakarya. Plant Omics Journal. 2010; 3(6): 204-209.

[51] Ngoh Dooh JP, Ambang Z, Ewola TA, Heu A, Kosma P, Maho YJE, Goghomu TR. Screening and the effect of extracts of Thevetia peruviana on the development of Colletotrichum gloeosporioides, causal agent of cassava anthracnose disease. Journal of Agriculture research and development. 2014; 4(4): 054-065.

[52] Harbone J. Phytochemical methods. A guide to modern techniques of plant analysis Chapman and Hall, London. $1973 ; 150$.

[53] Edeoga HO, Okwu DE, Mbaebie BO. Phytochemical constituents of some nigerian medicinal plants. African Journal of Biotechnology 2005; 4(7): 685-688.

[54] Jihani S, Brodoli K, Iraquil M, Ibnsoud S, Haggoudi A. Isolation and molecular identification of antibioticproducing actinomycetes from an old house in the medina of Fez, Morocco. Academics Journals. 2012; 6(47): $7370-7376$.

[55] Küster E, Williams ST. Production of hydrogensul-phideby streptomycetes and methods for its detection. Appl.Microbiol. 1964; 12: 46-52.

[56] Basse MB. Etude comparative de deux milieux de culture : plate count agar et marine agar, utilises pour la recherche de la flore mésophile aérobie totale dans les filets de sole tropicale congelés. Mémoire de DEA, Université Cheikh Anta Diop de Dakar. 2005; 39.

[57] Joffin JN, Leyral G. Microbiologie technique. Tome 1. Dictionnaire des techniques. 4ème ED. Académie de Bordeaux et CRDP d'Aquitaine. 2005; 171-189.

[58] Okumu MO, Mbara JM, Kanja LW, Gakuya DW, Kiama G, Ochola FO. Phytochemical profile and antioxidant capacity of leaves of Moringa oleifera (Lam) extracted using different solvent systems. Journal of Pharmacognosy and Phytochemestry. 2016; 5(4): 302-308.

[59] Essomé SC, Ngoh Dooh JP, Heu A, Ndogho A, Ngatsi ZP, Chewachong G, Ambang Z. Evaluation des activités antifongiques des extraits de graines de Thevetia peruviana contre Phytophthora colocasiae (Oomycètes) agent causal du mildiou du taro (Colocasia esculenta (L.) Schott) au Cameroun. J. Appl. Biosci. 2020; 151: $15584-15597$.

[60] Boulogne I. Evaluation du potentiel insecticide et antifongique sur Acromyrmex octospinosus (Reich) d'une sélection de plantes à usages ethnopharmacologiques TRAMIL. Thèse en biologie. Université des Antilles et de la Guyane. 2011; 183.

[61] Boulenouar N. Substances naturelles à visée antifongique : cas particulier des polyphénols. Thèse de Doctorat. Université d'Oran. Algérie. $2011 ; 182$.

[62] Zouaoui SA, Megherbi-Benali A, Toumi BF, Ouaar D. Contribution à l'étude du pouvoir antifongique des graines du Chenopodium quinoa wild vis-à-vis de deux champignons phytopathogènes de l'orge : Pyrenophora triticirepentis et Rhynchosporium secalis. Bulletin de la Société Royale des Sciences de Liège. 2018; 87: 100 -111.

[63] Kossonou YK, Kouakou-Kouame AC, Koffi AC, Koffi YM, Tra Bi fézan H, Tano K. Antifungal in vitro activity of five plants from local traditional medecine of Côte d'Ivoire on Colletotrichum Higginsianum, Fusarium Oxysporum and Rhizopus Stolonifer. 2019.

[64] Fons F, Amellal N, Leyval C, Saint-Martin N, Henry M. Effects of gypsophila saponins on bacterial growth kinetics and on selection of subterranean clover rhizosphere bacteria. Canadian Journal of Microbiology. 2003; $49 \mathrm{~N}^{\circ} 6$ : $367-373$.

[65] Millogo-Koné H, Kini BF, Yougbaré Z, Yaro MB, Sawadogo M. Etude de la phytochimie et de l'activité antimicrobienne in vitro des feuilles de Moringa oleifera (Moringaceae). Institut de Recherche en Sciences de la Santé, Burkina Faso. 2012 ; 16.

[66] Letoumeau L. Etude microbiologique de la carboxylation du phénol en conditions méthanogènes. Mémoire, Université du Québec. 1993; 189.

[67] Amrouche F, Namane A, Hellal A. Cinétiques de biodégradation du phénol par des bactéries autochtones librement suspendus dans un réacteur batch. Revue des Energies Renouvelables. 2011; 14 N³: 533-541.

[68] Zeboudj S, Loucif Seiad M, Namane A, Hank D, Hellal A. Elimination du phénol : couplage de l'adsorption sur charbon actif et la biodégradation par Pseudomonas aeruginosa. Rev. Microbiol. Ind. San et Environn. 2014; 8, $\mathrm{N}^{\circ} 1: 1-15$. 
[69] Buswell JA. Metabolism of phenol and cresols by Bacillus stearothermophilus. J. Bacteriol. 1975; $19: 1$ 1-14.

[70] Leitao Da-Cunha EV, Fechine IM, Guides DN, Maria BJ, Marcello SDS. Protoberberine alkaloids. The alkaloids, 2001; 75: 1099-4831.

[71] Conserva LM, Cynara A, Pereira B, José MBF. Alkaloids of the Hermandiaceae : occurance and a compilation of their biological activities. The alkaloids. 2005; 91: 1099-4831.

[72] Hibar K, Mejda Daami-Remadi, El Mahjoub M. Effets de certains fongicides de synthèse et biologiques sur la croissance mycélienne et l'agressivité de Fusarium oxysporum f. sp. radicis-lycopersici. Tropicultura. 2007; 25(3): $146-152$.

[73] Bribi N. Effet des alcaloïdes de deux espèces de Fumaria sur des bactéries multirésistantes d'origines hospitalière. Mémoire de Master, Université Abderrahman Mira de Bejaia. 2009; 84.

[74] Tabuc C. Flore fongique de différents substrats et conditions optimales de production des mycotoxines. Thèse de Doctorat, Institut National Polytechnique de Toulouse / Université de Bucarest. 2007; 190.

[75] Kennes C, Lema JM. Simultaneous biodegradation of p-cresol and phenol by the basidomycete Phanerochaete chrysosporium. J. Ind. Microbiol. 1994; 13: 211-314.

[76] Touré O. Etude de la biodégradation du phénol par Phanerochaete chrysosporium (ATCC-24725) et Pleurotus sajor-caju (NRRL-18757). Mémoire de Maîtrise, Université du québec. 1996; 153. 